\title{
A Survey of Students' Cognition of Acne and Their Self-Identity: A Case Study of a College in North Taiwan
}

\author{
Wei-Che Sung, James Ming-Hsun Chiang, Michel Plaisent and Prosper Bernard
}

\begin{abstract}
Acne is one of the common skin problems in adolescents and it is a multifactorial inflammatory disease of the skin. Facial acne affects not only appearance and mood, but also causes permanent scars on the patient's skin and even social problems. This study intends to use cosmetic and application science students from a certain specialty school in the northern part of the country as subjects to investigate the impact of cosmetics students on acne cognition and self-identity. The results showed that as many as $80 \%$ of the respondents had problems with acne, especially in the forehead, nose T-site; most students think that facial acne can cause confusion, inferiority and affect social interaction, the average degree of recognition of 3.8 points ( 5 subscales). The student's average recognition rate for acne is 71.3\%, and he believes that frequent staying up late, eating, stress, hormonal changes, improper facial cleansing are the causes of acne, less staying up late, looking at dermatologists, changing eating habits, and Facial cleansing is a way to improve acne. It is inferred that the students' knowledge and treatment of acne are still insufficient. They must strengthen the teaching of acne-related professional knowledge in beauty courses to prevent skin problems from affecting students' self-identity.
\end{abstract}

Keywords - Acne, Cognition, Cosmetics, College Students.

\section{FOREWORD}

Most acne cases occur during puberty, and are commonly referred to as "acne." Early on, acne was thought to be a physiological phenomenon in the process of growth; and with the advancement of medicine, acne has been considered as a chronic inflammatory disease of the skin, and it is not only a self-limited disease; its follow-up may cause appearances. Scars and psychological trauma, and may not be naturally healed. Foreign studies indicate that nearly $90 \%$ of young people are affected (Liu Zhengyi, 2002). The pathogenesis of acne is caused by a combination of factors, including hypersecretion of the sebaceous glands, hyperkeratosis at the opening of the hair follicles and sebaceous ducts, over proliferation of acne bacteria and inflammation, and endocrine disorders, stress, late nights, and sleep. Insufficiency and genetics, dietary habits, ultraviolet radiation and other factors may be the cause of acne.

In general, the treatment of acne by western medicine mostly depends on its severity to determine the treatment method, such

Wei-Che Sung, Department of Applied Cosmetology, Lee-Ming Institute of Technology,Taiwan, New Taipei City*,

James Ming-Hsun Chiang, Beijing Academy of Science Education, Beijing, China

Michel Plaisent and Prosper Bernard, dept. Management and Technology, University of Quebec in Montreal (Canada) as minor acne for external use of drugs, severe acne is treated with oral drugs or fruit acid peel, laser and other methods of treatment. Chinese medicine practitioners often use the three aspects of "differentiation," "differentiation," and "differential" for the treatment of acne medication. For example, the main basic syndromes of acne are pneumotracheal fever, spleen and stomach dampness, malocclusion, and coagulation. Prescription often use heat detoxification, cooling blood dampness prescriptions. In recent years, studies have suggested that gastrointestinal function is related to the pathogenesis of acne skin diseases. A study published for 13,000 adolescents showed that people with hemorrhoids are more prone to bloating, constipation, bad breath and acid reflux than other people, especially bloating, with about $37 \%$ of abdominal distension, possibly with hemorrhoids or fat leakage. Dermatitis related.

Modern people's diet and lifestyle habits have changed dramatically, and the problems associated with students' skin inflammation have become more diversified, and their perception of skin lesions may lead to negative physical and mental effects in the future. Therefore, the purpose of this study is to facilitate sampling methods to explore the causes of cosmetic acne patients and their improvement methods, as well as their impact on self-identity, in order to serve as a reference for future beauty education related curriculum design.

\section{RESEARCH METHODS}

The parent group of this study is a cosmetic and management science student in the Health Care Management College. Due to factors such as manpower, material resources, and time, it is not possible to conduct a general survey of all students. Therefore, convenience sampling is used to collect samples. The investigation time is 2014. March to April. A total of 75 valid questionnaires were retrieved in this study, and the recovery rate was $100 \%$. This study refers to the relevant literature to formulate a structured questionnaire, including a student's basic information. Second, acne has 5 questions (5-point scale) for self-identification of students. The higher the score, the higher the degree of recognition. Third, the students on acne cognitive topics 10 questions; the higher the rate of respondents, said that the higher the degree of awareness of facial acne, the questionnaire data to analyze the distribution of variables in percentage. 


\section{RESULTS AND DISCUSSION}

The survey found that nearly $80 \%$ of the students interviewed had problems with hemorrhoids. The most commonly occurring area of hemorrhoids was the forehead, which accounted for $59 \%$; the nose accounted for $32 \%$, the cheeks accounted for $31 \%$, the chin accounted for $28 \%$, and others included arms and The back and other parts accounted for 4\%, as shown in Figure 1.

(A)

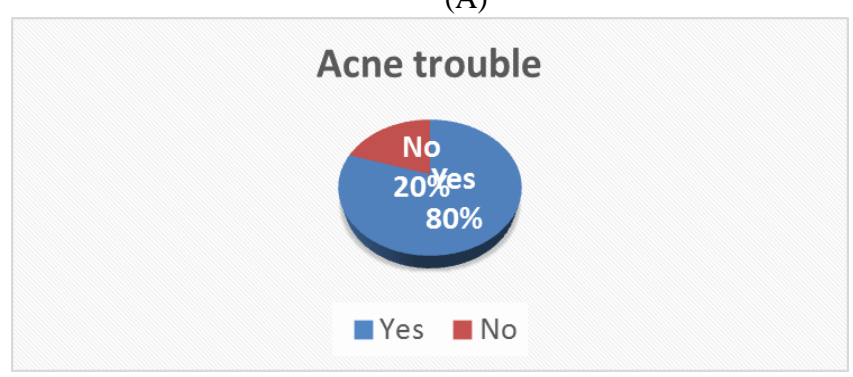

(B)

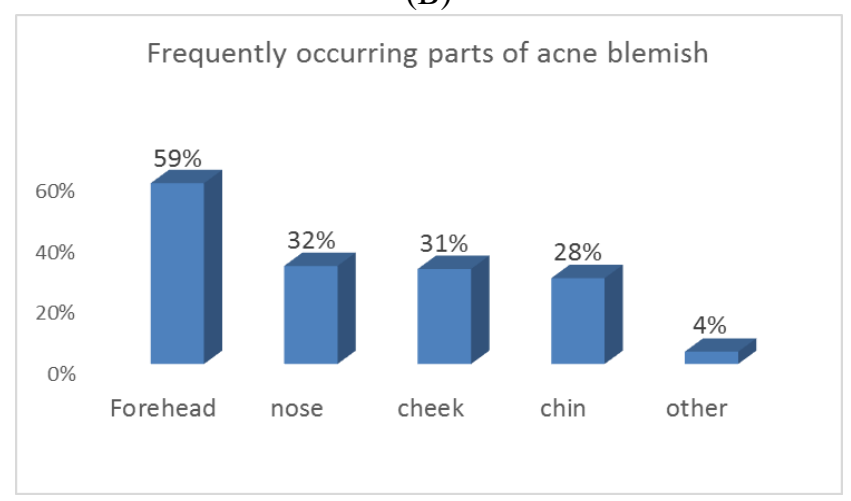

Fig. 1 College students had acne problem

Many studies have found that acne and the scars left behind can cause many negative psychological conditions in patients, such as anxiety, depression, and social interactions. This study found that severe acne problems on the face do cause problems for students, but also worry about affecting other people's perceptions and feelings of inferiority or interpersonal relationships, but they do not feel sympathy for students with acne problems, as shown in Table 1. It is speculated that most students think that hemorrhoids will affect others' opinions about themselves, and may even affect social relationships.

TABLE I:

THE IMPACT OF FACIAL ACNE ON COLLEGE STUDENTS' SELF-IDENTITY

\begin{tabular}{ll}
\hline \multicolumn{1}{c}{ Degree of acne and self-identity } & $\begin{array}{l}\text { Recognition degree (five-component } \\
\text { scale)* }\end{array}$ \\
\hline $\begin{array}{l}\text { 1. If you have trouble with face acne, } \\
\text { you will feel troubled }\end{array}$ & 4.6 \\
$\begin{array}{l}\text { 2. Facial acne can affect other } \\
\text { people's perception of themselves }\end{array}$ & 4 \\
$\begin{array}{l}\text { 3. Facial acne can affect one's } \\
\text { personal relationships }\end{array}$ & 3.5 \\
$\begin{array}{l}\text { 4. Hemorrhoids on the face will make } \\
\text { you feel inferior }\end{array}$ & 3.2 \\
$\begin{array}{l}\text { 5. Sympathetic to students with acne } \\
\text { on the face }\end{array}$ & 2.8 \\
\hline
\end{tabular}

*5 points: Strongly agree, 4 points: Agree, 3 points: Ordinary, 2 points: Do not agree, 1 point: Strongly disagree
This study further investigates students' related professional knowledge about the causes and methods of acne vulgaris. From Table 2, we can see that the average answer rate of acne specialists in cosmetic science students is about $72 \%$, especially for dietary nutrition. In addition, the majority of students believe that staying up late is the main cause of acne propulsion, accounting for $27.9 \%$; $18.8 \%$ dietary problems, hormones and stress $17 \%$, improper cleaning of the face $10.5 \%$, only $8.3 \%$ believe that with the skin glands Increase related, see Figure II. Worse, about $24.9 \%$ of students believe that staying up late is the most important way to improve acne; followed by dermatologists $(23.2 \%)$, changing dietary habits $(19.1 \%)$ and paying attention to hygiene practices $(14.1 \%)$. From this, it is inferred that even students of cosmetics-related departments have insufficient knowledge and treatment of acne.

TABLE II:

SURVEY OF FACIAL ACNE AWARENESS AMONG COLLEGE STUDENTS

\begin{tabular}{lc}
\hline Acne-related knowledge & 100 \\
\hline $\begin{array}{l}\text { 1. Moderately clean face helps prevent acne } \\
\text { 答 }(\%)\end{array}$ & 100 \\
$\begin{array}{l}\text { 2. Adequate sleep is the way to maintain healthy } \\
\text { skin }\end{array}$ & 96 \\
$\begin{array}{l}\text { 3. Controlling skin oil secretion helps prevent acne } \\
\text { 4. Acne is a skin condition caused by hair follicle } \\
\text { and sebaceous gland obstruction or inflammation }\end{array}$ & 89 \\
$\begin{array}{l}\text { 5. Excessive exposure to ultraviolet light can } \\
\text { promote inflammation of the skin and can also } \\
\text { cause acne }\end{array}$ & 69 \\
$\begin{array}{l}\text { 6. Acne may be a skin problem caused by the } \\
\text { proliferation of acne bacteria }\end{array}$ & 53 \\
$\begin{array}{l}\text { 7. Vitamin C in diet can promote collagen } \\
\text { proliferation and help wound healing } \\
\text { 8. Vitamin B in diet can maintain the normal } \\
\text { secretion of skin oil and prevent acne }\end{array}$ & 37 \\
\hline$\quad \quad$ Average answer rate & 31 \\
\hline
\end{tabular}

(A)

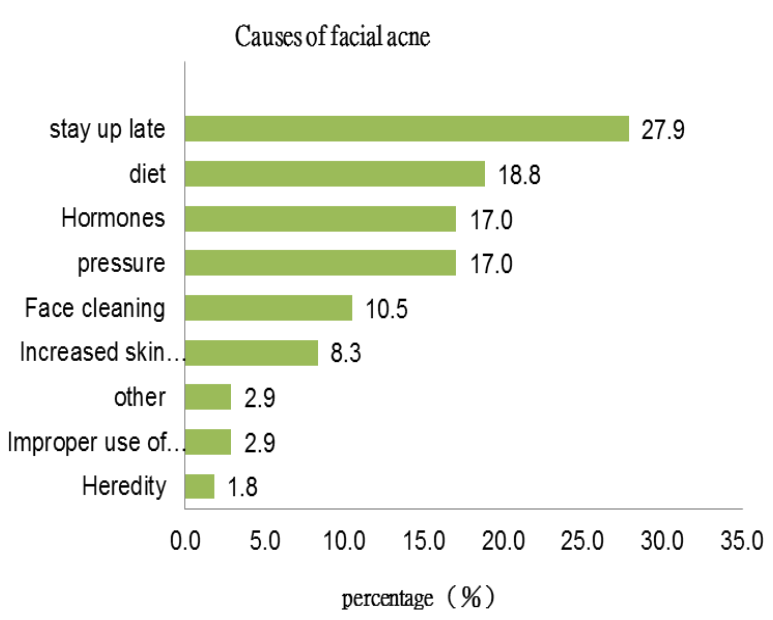


(B)

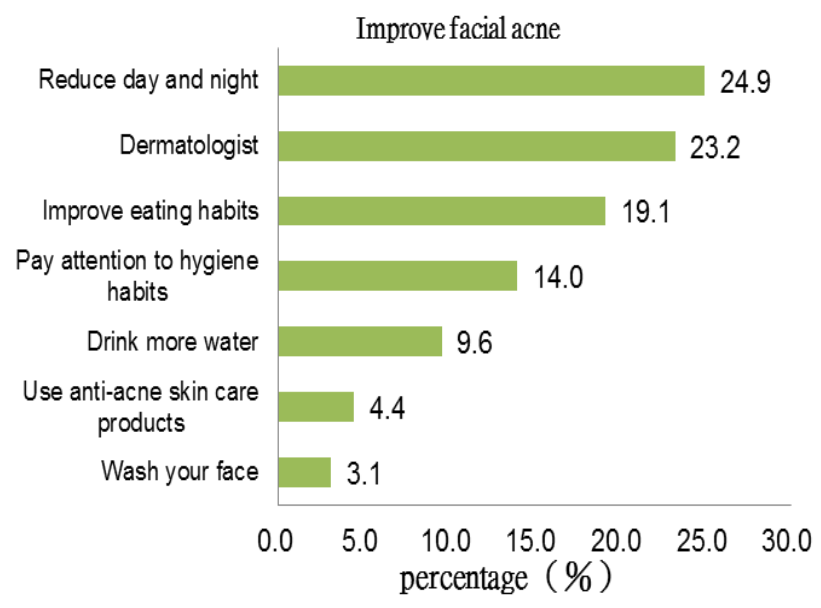

Fig. II: Awareness of College Students on Causes and Improvements of Facial Acne

Previously found that about $90 \%$ of the students have had hemorrhoids, and about $60 \%$ of them think that the growth of acne is related to the internal organs of Chinese medicine, and stress, endocrine disorders, foods and oils, and food and daily life are not. Normal and environmental factors are the main causes of acne, and it is believed that adjustment of daily routines and traditional Chinese medicine diets may improve acne conditions. In view of the fact that many studies have found that young students suffer from hemorrhoids, their awareness of acne-related awareness needs to be strengthened. It is suggested that the relevant professional knowledge of acne in health education should be strengthened in order to prevent skin problems from affecting students'self-identity. .

\section{REFERENCES}

[1] Thiboutot D1, Gollnick H, Bettoli V, Dréno B, Kang S, Leyden JJ, Shalita AR, Lozada VT, Berson D, Finlay A, Goh CL, Herane MI, Kaminsky A, Kubba R, Layton A, Miyachi Y, Perez M, Martin JP, Ramos-E-Silva M, See JA, Shear N, Wolf J Jr (2009): Global Alliance to Improve Outcomes in Acne: New insights into the management of acne: an update from the Global Alliance to Improve Outcomes in Acne group. J Am Acad Dermatol. 60(5 Suppl):S1-50. https://doi.org/10.1016/j.jaad.2009.01.019

[2] Fiedler F, Stangl GI, Fiedler E, Taube KM. 2017, Acne and Nutrition: A Systematic Review, Acta Derm Venereol. 4; 97(1):7-9. https://doi.org/10.2340/00015555-2450

[3] Reynolds RC, Lee S, Choi JY, Atkinson FS, Stockmann KS, Petocz P, Brand-Miller JC., (2010) Effect of the glycemic index of carbohydrates on Acne vulgaris. Nutrients, 2(10):1060-72. https://doi.org/10.3390/nu2101060

[4] 林宗輝、王育琇、萬昀柔、黃雅君 (2014) 皮膚疾病反映人體健康之 研究-以痤瘡為例, 休閒保健, 12:111-123。

[5] 呂建駒、顏啟華 (2014) 尋常性痤瘡致病機轉與治療新觀念, 家庭醫 學與基層醫療, 26 (1):14-18。

[6] 李采珍、蔡金川、洪裕強 (2016) 以實證研究及相關文獻探析痤瘡之 中醫「辩體」「辩病」「辨證」治療觀, 中醫藥研究論叢, $19(2): 75-87$ 